\title{
A new species, Orpbinus (Falsoorphinus) motykai sp.n. (Coleoptera: Dermestidae), from Japan
}

\section{Новый виА Orpbinus (Falsoorphinus) motykai sp.n. (Coleoptera: Dermestidae) из Японии}

\section{J. Háva \\ И. Гава}

\begin{abstract}
Daugavpils University, Institute of Life Sciences and Technology, Department of Biosystematics, Vienîbas Str. 13, Daugavpils LV5401 Latvia; Private Entomological Laboratory and Collection, Rýznerova 37, CZ-252 62 Únětice u Prahy, Praha-západ, Czech Republic. E-mail: jh.dermestidae@volny.cz.

Даугавпилсский университет, Институт естественных наук и технологий, отдел биосистематики, Даугавпилс LV-5401 Латвия; Частная энтомологическая лаборатория и коллекция, Прага, Чехия.
\end{abstract}

Key words: Taxonomy, new species, Coleoptera, Dermestidae, Orphinus, Japan.

Ключевые слова: таксономия, новый вид, Coleoptera, Dermestidae, Orphinus, Япония.

\begin{abstract}
The species Orphinus (Falsoorphinus) motykai sp.n. from Iriomote Island, Japan is described, illustrated and compared with similar species.
\end{abstract}

Pезюме. В статье описывается новый вид Orphinus (Falsoorphinus) motykai Hava, sp.n. из Японии (о-в Ириомоте).

\section{Introduction}

The genus Orphinus Motschulsky, 1858 recently contains 130 species divided into three subgenera worldwide. Six species known from Japan belong to the nominotypical subgenus and subgenus Falsoorphinus Pic, 1931 [Háva, 2015, 2020]. In the present study, a new species from Iriomote Island belonging to the subgenus Falsoorphinus Pic, 1931 is described below.

\section{Material and Methods}

The size of the beetle and of its body parts can be useful in species recognition, so the following measurements were made:

Total length (TL) - linear distance from anterior margin of pronotum to apex of elytra.

Elytral width $(\mathrm{EW})$ - maximum linear transverse distance.

Specimen of the presently described species is provided with red, printed label with the text as follows: «HOLOTYPE Orphinus (Falsoorphinus) motykai sp. nov. Jiří Háva det. 2020».

The following abbreviation is used to define the deposition of the mentioned material:

JHAC - Jiří Háva, Private Entomological Laboratory \& Collection, Únětice u Prahy, Prague-west, Czech Republic. [2015].

\section{Results}

Orphinus (Falsoorphinus) motykai Hava, sp. n. Figs 1-3.

Type material. Holotype (female): Japan, Okinawa Pref., Iriomote Isl., 0-400 m, Mt. Tedoyama, 13-22.May.2003, Bolm lgt. [A3667], (JHAC).

Description. Female. Body parallel and oval oval, TL $2.6 \mathrm{~mm}$, EW $2.2 \mathrm{~mm}$. Head, pronotum and scutellum black, elytra orange and black, shiny, covered by white-yellowish setation (Figs 1-2), black on venter. Head finely punctate with long, recumbent, white-yellowish setation. Palpi brown; setation on mentum denser. Labrum orange. Eyes large, with white microsetae. Ocellus on frons present. Antennae yellow with yellow setae, with 11 antennomeres, antennal club with 2 antennomeres, terminal antennal segment oval (Fig. 3). Pronotum black, disc finely punctate, densely foveolate posteriorly, with long, recumbent, white-yellowish setae. Scutellum black, triangular, without setation. Elytra orange with oval medial black spot and black anterior part, coarsely punctate; humerus with a small bump; elytral surface with long, recumbent white-yellowish and brown setation. Epipleuron orange, anteriorly broad, coarsely punctate, with short, white setation. Fore legs light brown with white setation (other legs missing). Meso-metasternum missing. Pygidium brown, with yellow setation. Abdominal visible ventrites III-V (I-II missing) black, with short, recumbent, white-yellowish setation.

Differential diagnosis. According to the structure of antennae, the new species belongs to the subgenus $\mathrm{Fal}$ soorphinus Pic, 1931. From other known species, it differs by the structure of antennae and arrangement of elytral spots. In the general appearance, the new species is similar to two known Japanese species: see the key below for differences.

Etymology. Patronymic, dedicated to my friend Michal Motyka (University Olomouc, Czech Republic). 

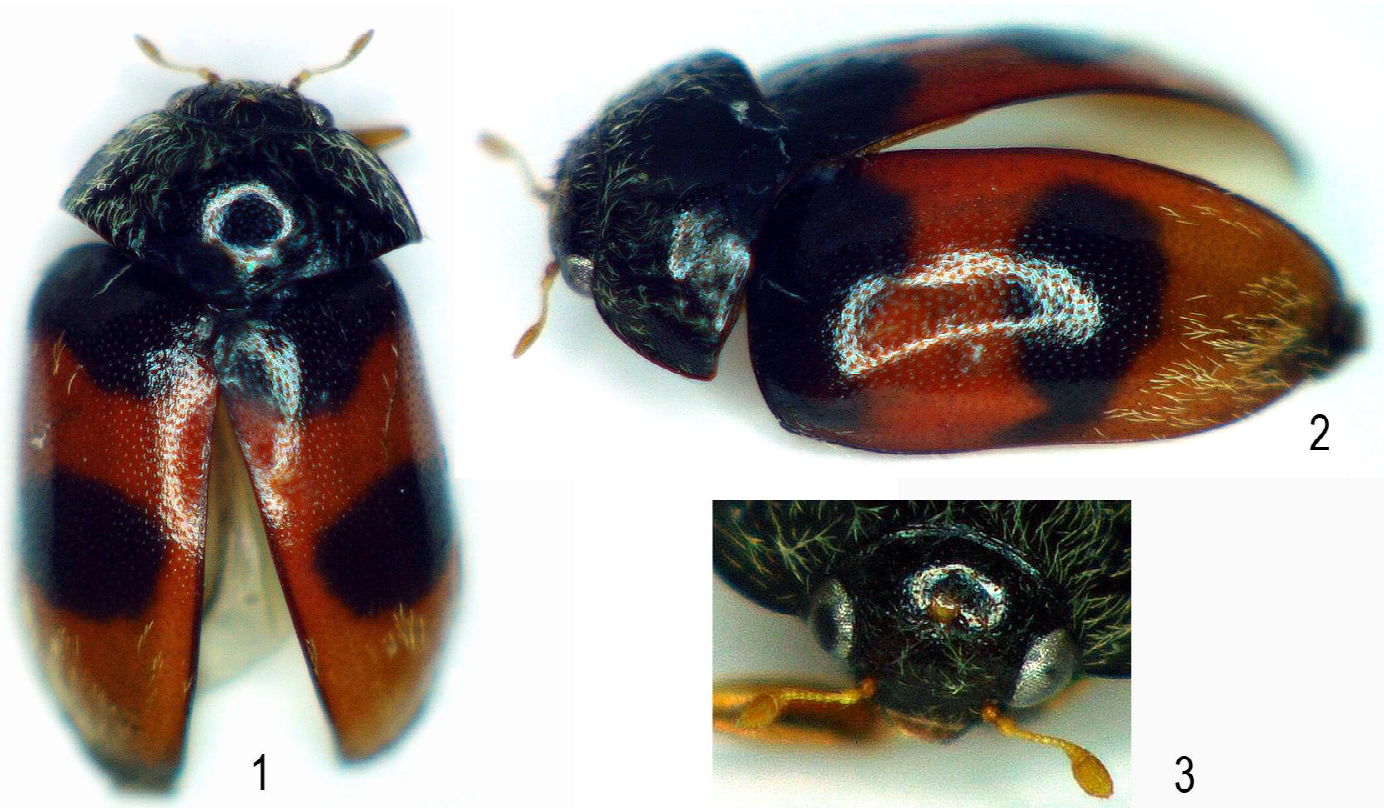

3

Figs 1-3. Orphinus (Falsoorphinus) motykai sp.n.: 1 - habitus, dorsal view; 2 - habitus, lateral view; 3 - antennae. Pис. 1-3. Orphinus (Falsoorphinus) motykai sp.n.: 1 - внешний виА, сверху; $2-$ внешний виА, сбоку; 3 - усики.

Remarks. The holotype specimen is not complete: the mesosternum, a part of the abdomen and five legs are missing. The damage resulted from the use of tissues for a further DNA analysis.

\section{Key to the JaPANESE $F_{\text {ALSOORPHINUS SPECIES }}$}

1. Elytra black with one transverse fascia and apical spot. ... 2

- Elytra orange with oval medial black spot and black anterior part Orphinus motykai Háva, sp.n.

2. Apical elytral spot very small, with white setation .......... . Orphinus okinawanus Háva, 2006

- Apical elytral spot very large or apical area of elytron entirely orange, with orange setation

Orphinus quadrimaculatus (Matsumura et Yokoyama, 1928)

\section{Acknowledgements}

I am indebted very much to Ladislav Bocák and Michal Motyka (University Olomouc, Czech Republic) for providing me with the interesting specimen.

\section{References}

Háva J. 2006. Orphinus (Falsoorphinus) okinawanus sp. nov. from Japan (Coleoptera: Dermestidae) // Entomological Problems. Vol.36. P.93-94.

Háva J. 2015. World Catalogue of Insects. Vol.13. Dermestidae (Coleoptera). Leiden/Boston: Brill, xxvi +419 p.

Kitano T., Háva J. 2018. A new species of the genus Orphinus Motschulsky, 1858 (Coleoptera: Dermestidae) from Japan // Studies and Reports, Taxonomical Series. Vol.14. No.2. P.397-400.

Hava J. 2020: Dermestidae world (Coleoptera). World Wide Web electronic publication (open in 2004): http://www.dermestidae. wz.cz (version 2018, update January 2020). 